This is an electronic reprint of the original article. This reprint may differ from the original in pagination and typographic detail.

Author(s): Chetty, Sylvie; Ojala, Arto; Leppäaho, Tanja

Title: $\quad$ Effectuation and foreign market entry of entrepreneurial firms

Year: $\quad 2015$

Version:

Please cite the original version:

Chetty, S., Ojala, A., \& Leppäaho, T. (2015). Effectuation and foreign market entry of entrepreneurial firms. European Journal of Marketing, 49(9/10), 1436-1459. https://doi.org/10.1108/EJM-11-2013-0630

All material supplied via JYX is protected by copyright and other intellectual property rights, and duplication or sale of all or part of any of the repository collections is not permitted, except that material may be duplicated by you for your research use or educational purposes in electronic or print form. You must obtain permission for any other use. Electronic or print copies may not be offered, whether for sale or otherwise to anyone who is not an authorised user. 


\title{
EFFECTUATION AND FOREIGN MARKET ENTRY OF ENTREPRENEURIAL FIRMS
}

\author{
Sylvie Chetty, Arto Ojala, and Tanja Leppäaho
}

\begin{abstract}
Purpose: The purpose of this study is to examine the decision-making process for entrepreneurial firms when entering foreign markets and how and why they entered those markets.

Design/methodology/approach: We combine a nascent theory in entrepreneurship called effectuation with internationalization process theory as the conceptual framework to study decision-making under uncertainty. The central concept in both these theories is relationships and how they can be used to gain knowledge and thus reduce uncertainty and in the case of effectuation to co-create opportunities to enter foreign markets. The research design involves a multiple case study of software firms from Finland and New Zealand.

Findings: We found that entrepreneurs differentiate between foreign market selection and foreign market entry during their internationalization process, potentially using different decision-making processes in them. They tend to interweave effectuation and causation logics as substitutes in their decision-making. Uncertainty during foreign market entry is not always a barrier because it can provide opportunities depending on the logic used. In addition, we have evidence that entrepreneurs who have existing relationships in foreign markets tend to use effectuation to select and enter foreign markets.
\end{abstract}


Originality/value: This paper transposes effectuation from its original field of entrepreneurship research to the context of internationalizing entrepreneurial firms. Consequently, it contributes towards understanding the decision-making process for selecting and entering foreign markets.

Keywords: internationalization; effectuation; causation; networks; entrepreneurship; foreign market entry; foreign market selection; software $\quad$ industry; $\quad$ international entrepreneurship

\section{Article Classification: Research Paper}




\section{INTRODUCTION}

A problem that internationalizing entrepreneurs frequently face is how much planning should they do before they start to internationalize and whether they should go alone or with partners into foreign markets. In this paper we aim to examine how internationalizing entrepreneurs make decisions about their foreign market entry (FME) and whether this is planned (goal driven) or unplanned (means driven). While there is a well-established stream of literature on the internationalization process of firms (e.g. Johanson and Vahlne, 1977; 2009), in this paper we add the entrepreneurial dimension. More specifically, our purpose is to shed light on how entrepreneurs make decisions and act during the FME process. The main research question is; how and why entrepreneurial firms decide to enter foreign markets?

The decision to invest in foreign markets is filled with risk and uncertainty and lack of information (Aharoni, 1966). While the uncertainty dimension has a central role in the internationalization process because of a lack of market knowledge (Johanson and Vahlne, 1977) there is scant literature about how this uncertainty could be reduced. One exception is Hilmersson and Jansson's (2012) empirical study which highlights the importance of experiential knowledge about the networks in the host country for uncertainty reduction in the market entry process. Another exception is Figueira-de Lemos, Johanson and Vahlne’s (2011) conceptual paper about uncertainty in the internationalization process. They propose that the extent of uncertainty about new foreign markets influences the firm's willingness to commit resources in order to make a FME. They illustrate how the pace and pattern of the firm's internationalization process is shaped by changes in uncertainty and commitment.

However, these studies do not focus on how entrepreneurs actually plan, make decisions, and implement their internationalization strategies under uncertainty. While scholars of 
internationalization have mainly focused on the contents of new venture internationalization strategies, the development and implementation processes of internationalization have gained scant attention (Zahra and George, 2002; Zahra et al., 2005). For instance, there is a gap in the literature investigating if and how entrepreneurs plan strategically, implement their internationalization, and select their foreign markets (Dow, 2000; Ojala and Tyrväinen, 2007; Ojala, 2009). Zahra et al. (2005: p. 143) expressed this as follows: 'We know little about what goes through entrepreneurs' minds as they explore their firms' competitive global landscape.'

In addressing this research gap, we aim to use an emerging theory called effectuation to help us understand decision-making under uncertainty which in this paper pertains to FME. Effectuation has recently captured the interest of entrepreneurship researchers (see e.g. Brettel et al., 2012; Chandler et al., 2011; Fisher, 2012; Perry et al., 2012). The traditional entrepreneurship perspectives concentrate on the entrepreneurial action and discovery of opportunities (see Casson, 1982; Shane and Ventakamaran, 2000) related to strategy approaches (Ansoff, 1988), which is described by Sarasvathy (2001) as causation logic. Effectuation (Sarasvathy, 2001) has emerged as an alternative theoretical perspective for describing entrepreneurial action. In fact, there is recent evidence suggesting that effectuation explains the actions of entrepreneurs better than causation (see e.g. Fisher, 2012).

We combine internationalization process theories (Johanson and Mattsson, 1988; Johanson and Vahlne 1977, 2009) and effectuation approach (Sarasvathy, 2001; Read et al., 2009) to form our conceptual framework to study decision-making under uncertainty. Furthermore, we build on previous research that has initiated the process of integrating effectuation and internationalization process (see Mainela and Puhakka, 2009; Sarasvathy et al. 2014; Schweizer et al., 2010). Both effectuation approach and Uppsala model have relationships as a central focus to provide knowledge and opportunity (Johanson and Vahlne, 2009; Sarasvathy, 2001). While 
internationalization process theory focuses on relationships at the firm level, effectuation focuses on relationships at the individual entrepreneur level, therefore allowing us to add the entrepreneurial dimension to internationalization process theory. Since we use the effectuation approach the alternative assumption of Palich and Bagby (1995) that entrepreneurs are predisposed to being optimistic by perceiving positive outcomes rather than predisposition to taking risks, resonates with our study.

\section{THEORETICAL BACKGROUND}

In this section, we discuss Sarasvathy's $(2001,2008)$ approach $^{1}$ on causation and effectuation in entrepreneurial behavior. Thereafter, we discuss how causation and effectuation are connected to the theories focusing on firms' early internationalization.

\section{Causation and Effectuation Approaches}

Sarasvathy (2001) introduced effectuation approach to describe how entrepreneurs behave when creating new ventures. In this seminal piece she differentiates between causation and effectuation to draw out their key elements. Causation processes take a particular effect as given, and focus on selecting the means to create that effect. In contrast, effectuation processes take as given a set of means, and focus on selecting between the possible effects that can be created with such means (Sarasvathy, 2001).

\footnotetext{
${ }^{1}$ We use the term 'approach' to refer to causation and effectuation, since it is in its nascent stage of development in the literature. We acknowledge that there are debates about the correctness of the use of terms such as 'theory' and 'model' in relation to new approaches that are evolving in the literature (see e.g. Andersen, 1993).
} 
There are two kinds of 'problems' in causation and effectuation logics. Causal problems are problems of decision, whereas effectual problems are problems of design (Sarasvathy, 2008). Sarasvathy (2008) points out that causation logic helps us to choose and effectuation logic helps us to construct. In other words, the causal actor begins with an effect (s) he wants to create and asks: 'What should I do to achieve this particular effect?' (Sarasvathy, 2008: p. 73). For instance: 'What should I do for FME?' Thus, causation logic follows a certain procedure. One good example of this includes Kotler's (1991) suggestion for bringing the product/service to market. It involves (i) analyzing long-run opportunities in the market, (ii) researching and selecting target markets, (iii) designing marketing strategies, (iv) planning marketing programs, and (v) organizing, implementing, and controlling marketing effort. In contrast to causation, the person using effectuation begins with his/her means and asks: 'What can I do with these means?' And then again 'What else can I do with these means?' (Sarasvathy, 2008: p. 73). The context can be, for instance, 'We are now five internationalization specialists here and we have this kind of knowledge and contacts. What could we do together?' Sarasvathy (2008: p. 73) summarizes this as follows: 'Effectuation does not begin with a certain goal; it begins with a given set of means and allows goals to emerge contingently over time from the varied imaginations and diverse aspirations of the founders and the people with whom they interact.'

Causation focuses on the logic of prediction (Sarasvathy, 2001); to the extent that one can predict the future, one can control it. Effectuation emphasizes the logic of control, i.e., to the extent that you can control the future, you do not need to predict it. Organizations that use effectuation make decisions on the basis of existing means, i.e. identity, knowledge and network. Effectuation logic emphasizes that entrepreneurial opportunity, discovery process and uncertainty are situation dependent (Sarasvathy et al., 2003). When using effectuation logic, the entrepreneur ignores risk prediction and makes decisions on the basis of loss absorption to control uncertainty. 
Effectuation reasoning transforms uncertainties to opportunities as they avoid early commitment to any specific markets (Sarasvathy et al., 2003).

Effectuation logic focuses on partnerships to acquire resources as opposed to causal competitive analyses to develop strategies to outdo competitors. In causation logic, the market is expected to exist independently of the firm or entrepreneur and the aim of the entrepreneur would be to grab as big a share of that market as possible (Sarasvathy, 2001). In effectuation logic, the founder collaborates with others to create the market by bringing together enough stakeholders who are committed to sustain the enterprise. For example, a customer who is interested in the firm’s products invests in the business to share ownership. According to Sarasvathy (2001: p. 252): 'Effectuation emphasizes strategic alliances and pre-commitments from stakeholders as a way to reduce and/or eliminate uncertainty and erect entry barriers.’

\section{Causation and effectuation in the context of internationalization}

The Uppsala model (Johanson and Vahlne, 1977; Johanson and Wiedersheim-Paul, 1975) describes internationalization as an incrementally evolving process, in which a firm internationalizes its operations by gradually increasing its involvement in a market. In the market selection, firms are expected to first enter nearby markets that are psychically close, as they want to avoid uncertainty related to more distant markets (Johanson and Wiedersheim-Paul, 1975). Thereafter, when a firm's knowledge of how to operate internationally increases, it gradually starts to develop activities in psychically more distant countries. Hence, the Uppsala model represents risk avoidance that is related to causation logic (Frishammar and Andersson, 2009). Johanson and Vahlne (2009: p. 1432), however, argue that: 'The effectuation process has much in common with our internationalization process.’ 
In an emerging stream of research that integrates effectuation and internationalization. Schweizer et al. (2010) adjust the Uppsala model to include a dimension which considers internationalization as an entrepreneurial process because entrepreneurs identify and develop opportunities in their networks. The internationalization process that Schweizer et al. (2010) describe when developing the model are mainly effectuation processes. Sarasvathy et al. (2014) are influenced by Schweizer et al.'s adjusted model and subsequently develop a model that integrates effectual approach to international entrepreneurship. Sarasvathy et al. (2014) identify three characteristics of internationalization that they consider would benefit from effectuation. These include; cross-border uncertainty, limited resources and network dynamics. Sarasvathy et al. (2014 p. 76) state; 'effectual variables such as who the founding entrepreneurs are, what they know, and whom they know will be important to IE [international entrepreneurship] research.' In addition, that the principles of effectuation may help deepen our understanding of 'the how to internationalize question including why, when, where and how fast to internationalise' (Sarasvathy et al., 2014: p. 84).

While the internationalization process model and effectuation approach highlight the positive aspects of relationships to acquire resources, several scholars have pointed out that relationships can have a negative aspect. Chetty and Agndal (2007) illustrate how relationships can be a liability during the internationalization process when one partner behaves opportunistically. They found that opportunism often instigated the firm to change its internationalization strategy so that it could exit a partnership. Gulati et al. (2000) explain how firms can be locked into poorly performing relationships which constrain firms from taking advantage of better opportunities that other relationships offer. In the paradox of overembeddedness Uzzi (1997) highlights how a closed network prevents new ideas and information to enter it. Thus effectual networks used in foreign market selection (FMS) and FME 
can be limiting if members behave opportunistically or the network is closed. Since entrepreneurs using effectuation are reliant on new ideas and new ways of introducing their products to foreign markets they need to embrace new knowledge.

International new venture (INV) theory suggests that internationalization is not always an incrementally evolving process (Oviatt and McDougall, 1994) as founders of new ventures can use their existing knowledge and relationships to enter foreign markets soon after their firms are founded. Based on INV theory, internationalization is related to opportunity-seeking behavior where an entrepreneur: 'seeks to derive significant competitive advantage from the use of resources and the sale of outputs in multiple countries’ (Oviatt and McDougall, 1994: p. 49). In addition, effectuation logic highlights the importance of relationships; 'who I know' (Sarasvathy, 2001). In many cases, these relationships have an important role in a firm's internationalization (Chetty and Campbell-Hunt, 2003; Johanson and Mattsson, 1988; Johanson and Vahlne, 2009) as network relationships may serve as a bridge to new foreign markets (Johanson and Vahlne, 1990).

In their seminal article, Johanson and Vahlne (2009) focus on the importance of insidership in networks. Insidership denotes relationships that are developed before internationalization and which help to overcome the 'liability of outsidership' in a foreign market. When a firm is inside the network it gains trust, legitimacy and knowledge about the foreign market. In addition, network relationships may have a critical role in market selection, as firms tend to follow their existing relationships to foreign markets (Coviello and Martin, 1999; Moen et al., 2004). These existing relationships tend to drive firms to enter nearby markets that are psychically close. One explanation is because when psychic distance becomes greater, it makes network formation more challenging (Johanson and Vahlne, 2009; Ojala, 2009). One benefit of combining previously separate networks, however, is that unexpected new ideas and 
paths emerge (Powell and Sandholtz, 2012) which could occur when the firm enters markets with a greater psychic distance.

Table 1 provides a comparison of the main categories identified in causation and effectuation approaches and the internationalization process model that are relevant for the FME decision-making process. By selecting these dimensions we build on previous work by Sarasvathy et al. (2014) and Schweizer et al. (2010) which highlights the importance of knowledge to reduce cross-border uncertainty and the central role of relationships to acquire resources, and network dynamics.

'Insert Table 1 here'

\section{METHODOLOGY}

We selected software firms as a target group because of their international focus, leadingedge technology, high knowledge-intensity, innovation-driven market growth, and high growth strategy. Furthermore, software firms are exemplars of entrepreneurial firms' growth strategies (Brouthers and van’t Kruis, 1997; Tsang, 2005; Zahra and Bogner, 2000) and internationalization (Coviello, 2006). We use Carland et al's. (1984) characteristics of entrepreneurial firms to define our firms ${ }^{2}$. The characteristics that are particularly pertinent for our entrepreneurs include; risk bearing, innovation and growth oriented. Innovation includes innovative combination of resources (Carland et al., 1984) which suits our study as entrepreneurs built relationships to combine resources in an innovative way to reduce risk and uncertainty in order to grow by entering foreign markets. We include the alternative assumption of Palich and Bagby (1996) that

\footnotetext{
${ }^{2}$ In this study, we are applying an individual level analysis. That is, by studying the main decision makers within the entrepreneurial firm, we can form an understanding of the firm's behavior.
} 
entrepreneurs are optimistic and see opportunities where others would see weaknesses or threats. This is consistent with effectuation which focuses on turning uncertainty into opportunities. Since entering foreign markets includes uncertainty and risk due to many unknown variables we follow Palich and Bagby's (1996) rationale that entrepreneurs need to be optimistic and believe in a positive outcome to pursue this activity.

We selected multiple case study method because we wanted to cover a real-life environment in which causation and/or effectuation processes take place. Thus, the research method had to be appropriate to cover the spheres of human actions and to enable an in-depth investigation of the complex phenomena. In relation to decision-making at the entrepreneur level, Sarasvathy (2001: p. 261) argues that '...case studies and qualitative analyses of detailed decision-making experiments might be required to accomplish this empirical objective.' The case study method has also been used in several earlier studies related to decision-making processes (e.g. Eisenhardt, 1989b).

Since the selection of cases influences the results of the study (Miles and Huberman, 1994), we used multiple criteria to select cases. One of the selection criteria was good access to the required information, as recommended by Stake (1995). Thus, the entrepreneurs were contacted based on the industry knowledge and contacts of the authors. The personal-contact aspect increased mutual trust between the researcher and the interviewees, and consequently, facilitated the collection of accurate information. The selection of cases is not only confined to good access to the information, as the theoretical perspective has to be also taken into account (Eisenhardt, 1989a).

We follow theoretical replication logic suggested by Eisenhardt and Graebner (2007: p. 25), which forms 'bridges from rich evidence to mainstream deductive research', by focusing on the following issues when selecting our cases. Firstly, the cases selected for this study are from 
Finland and New Zealand. Although the business environment in these countries is rather similar, differences in their geographical location may have a great impact on the internationalization behavior of these firms (Ojala and Tyrväinen, 2007). Furthermore, both countries are both small and open economies, where internationalization is essential for growth. As Casey and Hamilton (2014) found the success of small firms from small open economies such as New Zealand are crucial because these firms are propelled into foreign markets due to the small size of their domestic markets. It is through successful internationalization that these firms grow beyond what the domestic market would enable them to do. Secondly, the firms' products and consequently their targeted customers varied from traditional industries like the furniture industry to high-tech industries such as telecommunication. Thirdly, the foreign market entries of the firms varied greatly from nearby to more distant markets. Altogether, the selected sample covers a broad range of firms from the software industry. This is important for studies having a small sample of firms (Schweizer, 2005) since it should include 'polar types’ of research sites (Pettigrew, 1990). This allowed us to obtain rich insight about the software industry as a whole. Finally, the criteria for selecting the firms were that the number of employees should be 250 or less full-time employees, which is a definition used in studies focusing on European and/or New-Zealand small and medium-sized enterprises (SMEs) (see e.g. Agndal and Chetty, 2007; Loane et al., 2007). The profiles of the firms are summarized in Table 2.

'Insert Table 2 here'

We used multiple sources of information to gather data from each case firm. The main form of data collection was in-depth interviews conducted with the chief executive officers (CEOs) and managers involved in decision-making for the internationalization process. Semi-structured 
open-ended interviews lasting between 90 minutes and 160 minutes were conducted with ten firms for this study. Five firms were from Finland and five firms from New Zealand. CEOs, sales, marketing and international business managers were selected as interviewees for this study as they had the most in-depth knowledge concerning foreign market entries of the firm. We focus on the first three foreign markets entered by the firms. The rationale is that in the context of entrepreneurship and internationalization the early phases are critical as they determine the firms' subsequent growth. Furthermore, the entrepreneurs in these firms will have vivid memories of the critical incidents relating to the first few markets they entered (Gruber et al., 2012). The likelihood of retrospective bias is low since the early phases of internationalization deal with an event of significant importance (Akerlof and Yellen, 1985). In addition to interviews, we used many sources of secondary information, such as press releases, firms' websites, annual reports etc.

By using semi-structured, open-ended questions we were able to ask the 'main' questions and then pose further, more detailed questions (Yin, 2003). The interviewees were first asked to describe their business in general and the internationalization history of the firm. Interviewees were then asked to explain the circumstances that led to the FMS and how they entered these markets. Based on this general information, more detailed questions were then asked about the important events, persons, firms, or organizations involved in the FME. All these questions were developed according to the guidelines by Yin (2003), with the aim of making them as open-ended as possible. This encouraged the interviewees to give authentic answers. Since interviews focused on the entrepreneurs' past experiences, we followed the guidelines for retrospective studies issued by Miller et al., (1997) and by Huber and Power (1985). Hence, we (i) compared information provided by the informants, (ii) asked about concrete events and facts, (iii) encouraged informants to give precise information rather than past opinions or beliefs, and (iv) 
used the written material of the firm to facilitate the recall of past events. If interviewees were unsure about an important event in the past, we asked them to check their emails to help recall how the event progressed. This worked well as most interviewees saved their emails.

All the interviews were digitally recorded and transcribed verbatim. The complete transcripts were then sent back to interviewees for review. Mostly, the interviewees confirmed the accuracy of the transcripts. In addition to face-to-face interviews, we used telephone and email communication to collect further information and to clarify inconsistencies where necessary. By comparing the interview data with other information gathered from the firms, we conducted triangulation of the information (Miles and Huberman, 1994).

We used content analysis to analyze the data. The analysis of the case data consisted of three concurrent flows of activity (Miles and Huberman, 1994): (i) data reduction, (ii) data displays, and (iii) conclusion-drawing/verification. In (i) the data reduction phase, the data were focused and simplified by writing a detailed case history of each firm. This is in line with Pettigrew (1990), who suggests that organizing incoherent aspects in chronological order is an important step in understanding the causal links between events. On the basis of the interviews and other material collected from firms, we identified and categorized the unique patterns of each case under the sub-topics derived from the research questions. In addition, checklists and event listings were used to identify critical factors related to the phenomena encountered (Miles and Huberman, 1994). In (ii) the data display phase, the relevant data were collected in tables. In (iii) the phase of conclusion-drawing and verification, we concentrated on identifying the aspects that appeared to have significance. At this stage we noted regularities, patterns, explanations, and causalities relating to the phenomena.

During coding and categorization of the data we followed Sarasvathy's (2001) theoretical distinction between causation and effectuation very carefully when selecting the narratives from 
the transcripts to categorize the firms FMS and FME. We went through the transcripts to identify statements about FMS and FME events and whenever possible categorized them according to causation or effectuation logic using pattern matching techniques from Miles and Huberman (1994). Hence during data analysis we followed a systematic approach by constantly moving back and forth between the data and theory to isolate patterns of causation and effectuation logics. This systematic coding and analysis allowed us to tease out these patterns to link them with FMS and FME and thus connect the data with the results of this study. After this attempt at systematic categorization we realized that it is difficult to make a clear cut distinction between causation and effectuation as causal and effectual elements are sometimes intertwined. Thus our categorization in Table 3 indicates narratives that are more inclined towards causation or effectuation elements rather than in their pure form. In other words the narratives provided a nuanced picture of causation and effectuation. While these logics can be seen as two anchor points to highlight their differences they are interwoven. During the coding of the data we went through the transcripts and looked for events relating to FMS and FME and then themes relating to networks, FME, FMS, planning, unexpected events, competitor analysis, market research, goals etc. We use these events, themes, and the internationalization process theory (Johanson and Vahlne, 1977, 2009) and effectuation approach (Sarasvathy, 2001), to develop four testable propositions for future research. In addition, we moved back and forth between the theory and data when developing these propositions.

The researchers in both countries went through the transcripts to categorize the firms' FMS and FME separately. We subsequently worked jointly to compare and cross-check our categorization of whether the firms' FMS and FME followed causal or effectuation logic. By initially working independently on this data analysis, researchers in each country were able to; '... compare, challenge and synthesise 'insider' and 'outsider' perspectives to provide cross 
country comparisons' (Marschan-Piekkari and Welch, 2004). We dealt with ambiguities and variations in categorization by clarifying the conceptualization of causal and effectuation logics.

\section{ANALYSIS OF FOREIGN MARKET SELECTION AND FOREIGN MARKET ENTRY OF THE FIRMS}

While analyzing the degree of causation and effectuation in the foreign market entries of the firms, we recognized that the target country selection and the way that the firms actually entered these markets could be divided into two different 'problems'. The first problem was related to FMS, that is, if the FMS was based on the problem of decision (causation) or the problem of design (effectuation). The second problem was related to how the firms entered the foreign market. The FME could also be divided into causation or effectuation. While the FMS of a case firm may be based on causation logic, the FME may be based on effectuation logic. Table 3 provides an overview of these logics used by the firms in their FMS and entry. In addition, it provides quotes from the interview data to demonstrate how the interviewees expressed the circumstances that led to their FMS and FME. This distinction for FMS and FME also helped to recognize the intertwining of causation and effectuation elements in decision-making and implementation processes.

'Insert Table 3 here'

Foreign Market Selection of the Firms 
Most of the Finnish firms followed causation logic in their FMS (see Table 3). The reasons for this were related to the fact that entrepreneurs of these firms already planned, in the establishment phase, the main foreign market where they wanted to locate in the future. For instance FIN1, which develops a cloud gaming platform for Internet protocol televisions (IPTVs), knew that they had to locate in the markets that offered good contacts either for game development studios or IPTV providers. For this reason they first entered the UK market because it offered good contacts (insiders) with game development studios (technological environment). Consequently, two market entry decisions, Japan and the USA, were based on the location of IPTV providers. In a similar manner, during the establishment phase of FIN3 one of the cofounders already knew the central markets where they wanted to be located. They provided risk management software for banks, so for them it was important to locate in the cities with well-known financial centers (institutional environment). As the CEO stated;

'We have been very determined in our internationalization strategy. Frankfurt is the financial center in Europe, Paris is the place where you have to be, and in Russia if you want to do something you have to be located in Moscow.'

Similar to FIN1 and FIN3, the FMS of FIN5 followed causation logic. Since the firm provides 3D modeling software for furniture manufacturers and furniture chain stores, the cofounders of the firm wanted to be located in European countries with a strong furniture industry. For this reason they decided that their first market to enter should be Italy since it has a long tradition in the furniture industry. They subsequently entered the Nordic countries such as Sweden and Denmark for the same reason. The CEO of FIN4 made the decision to first enter Sweden because the implementation of the company's access rights management software requires intensive cooperation with customers. They decided it was safer to start there because Swedish customers (financial institutions) operate in all Nordic countries. 
Interestingly, FIN2 was the only case firm that used effectuation logic in their FMS. For their first FMS, they obtained an order from an existing partner who had a project in the US market that required FIN2's knowledge to complete. Their third FME, this time into Japan, was also at the behest of an existing partner suggesting a joint project. Thus, these two decisions were not based on a planned strategy, but rather involved capitalizing on unexpected opportunities. Their market entry into Singapore followed causation logic because they believed it had good potential to expand their business to Southeast Asian markets.

Although most of the Finnish firms were rather decisive when entering certain markets, they were still open to new opportunities and allowed for affordable loss. This implies that causation and effectuation are used as substitutes. The CEO of FIN3 expressed it as follows:

'We cannot focus on all markets at the same time. Of course if someone comes and asks about our product, we can show our demo version and have a meeting with the potential customer. We now have two cases like this, one from Brazil and one from Singapore. They might be our future customers... we cannot say 'no' to them but we are not actively focusing on these markets.'

Most of the New Zealand firms were inclined to follow effectuation logic when selecting their markets as can be seen in table 3 . This is because they relied predominantly on their relationships to increase their means for FMS. They selected their foreign markets based on existing relationships with large, reputable companies with worldwide markets. Through such relationships they selected multiple countries wherever their partners take them. Thus stakeholders committed to the firm's internationalization growth and co-created further opportunities for expansion. For example, through a major partner NZ1 co-created its international markets. NZ1's FMS into Australia was initiated through a multinational (MNC) company it worked with in New Zealand. Despite initial difficulties in Australia, the next FMS 
was Hong Kong in response to its MNC partner’s encouragement. The third FMS was the United States, which NZ1 entered through its existing partnership with the MNC. The MNC's invitation was a result of its favorable experiences with NZ1 in Australia.

Similarly, NZ2 selected the Australian market in 1988 by leveraging off its relationships with its major clients (which includes leading multinational companies) in New Zealand who were doing business in Australia. While previous examples of New Zealand firms' FMS were based on effectuation logic, NZ3 provides evidence for causation logic because it had a strategic plan. For example, from inception it recognized the opportunity to sell on the internet and achieved international sales quickly because of this early adoption. In addition, serendipity had a role to play in FMS as illustrated by NZ5, which was originally established in 1978 to produce energy savers for large-scale industrial uses. A related development in soft starter technology was to become the company's ultimate focus. This resulted in NZ5 becoming the world's leading independent producer of soft starters for the pumping, mining, forestry and marine industries.

\section{Foreign Market Entry of the Firms}

Although FMS of the Finnish firms was mainly based on causation logic, the way they actually entered these foreign markets was more in line with effectuation logic. Thus illustrating how causation and effectuation are intertwined and used as substitutes. After deciding about the target market(s), the firms started to search for existing resources by asking 'whom do we know?' and 'what we can do with these resources?' That is, most of the FMEs were based on the entrepreneurs' use of existing resources. FIN1, FIN2, FIN3, and FIN5 used their own, internal relationships for their FMEs. For instance, FIN1 was able to establish a sales office in the UK through one of the cofounders' personal relationships, which extended to a London-based 
individual who had the relevant knowledge to market FIN1's products. FIN3 was able to use the personal contacts of an advisory board member to enter France and Russia, and the personal relationships of the cofounder to enter Germany. The CEO explained this as follows:

'Without these contacts we would have to make so many trial and errors before we could find someone [customer or partner] by luck [from the target country]'.

In addition, partners formed important external network resources in the FMEs of FIN1, FIN2, and FIN5. FIN1 used their partner's contact who was already selling products to Japan to enter that market. FIN5 attended international trade fairs to look for a partner to handle the Swedish market. They found an erstwhile competitor who opted to cooperate as a partner in the Swedish market. Additionally, partners were found at an international trade fair (FIN1, third FME) or 'accidentally' where a future partner made contact with FIN5 when FIN5 displayed its products on the Internet (FIN5, first FME). This indicates the intertwining of causation and effectuation logics. Only two of the Finnish firms used causation logic in their FMEs. FIN4 hired an external consultant to find a partner to handle the Swedish market. This was mainly due to the lack of relevant relationships and the willingness to find the best possible partner from Sweden. In a similar manner, FIN5 used the services of the Finnish export promotion organization to find an employee to handle the Danish market. The CEO explained:

'We needed someone [for the Danish market] who had knowledge about the furniture industry, especially from an international point of view.'

NZ firms were more likely to use effectuation logic when entering foreign markets. They relied on existing partnerships, former employees and joint venture partnerships to enter their foreign markets. For example, NZ1 entered the Australian market in September 1996, facilitated by the CEO/Founder's relationships with a multinational company (MNC) already operating in Australia. Thus, using effectuation logic NZ1 began with its means, asking: 'what can I do with 
these means and with this partnership?' NZ1s CEO/Founder admits that when they first started to internationalize they were poorly prepared, which illustrates their willingness to take risks and enter the unknown. NZ1 demonstrated effectuation logic by using its means (product and partner) and following its partner MNC to select and enter Hong Kong. It was a question of: 'what else can I do with this existing product and existing partner?' Another example of a means-driven approach is NZ2, which entered the US market by forming a joint venture partnership with a customer ('who do I know?') who also invested in the business.

While New Zealand firms typically followed effectuation logic in FMS we found two counter examples of causation logic. For instance, NZ5 used causation logic when it eventually realized that it would have to be more proactive in selling the benefits of the soft starter. Although FMS in the US and Australia have been goal oriented by attempting to be in the right place at the right time this did not always occur as planned so effectuation kicked in. As the CEO of NZ5 explains:

'...a lot of that is relationship and timing, which you can't create... So here we've got to be doing the right things, having the right product, then the right kind of company and you've just got to keep at those people that you think are a good relationship...'

Although NZ5 followed causation logic twice for FMS, the fact that NZ5's CEO mentions unpredictability of relationships and timing [showing uncertainty] for FME indicates effectuation, thus illustrating the overlapping of these logics. Another example is NZ3, whose FMS followed causation logic in deciding to sell online to the US, whereas its FME followed effectuation logic, as the following quotes from the CEO illustrate:

'We create our own opportunities.' 
'You started making a few sales and you invested your time and the products that sold better, the idea that had more potential and away you went. There was no five-year plan or anything like that. We still don't have a business plan'

\section{DISCUSSION}

We provide empirical evidence for the decision-making process relating to selecting and entering foreign markets by using Sarasvathy's $(2001,2008)$ causation and effectuation approach and building on Schweizer et al. (2010) to expand its usefulness into the context of FME decisionmaking. The inclusion of causation and effectuation logic allowed us to find a distinction in the decision-making process between FMS and FME, thus contributing to internationalization theory which has focused only on FME. Since the effectuation approach and Schweizer et al.'s (2010) model are iterative and dynamic (Sarasvathy et al., 2014) this allows us to capture the complexity of decision-making for the FMS and FME. Thus FMS and FME affect each other through several cycles of decision-making showing that the process is not linear as actions and decisions interplay thus making them complex and dynamic. In addition, we found that effectuation logic was related to the task at hand, levels of uncertainty, and institutional and technological environment (see table 3).

FMEs to the target countries were inclined towards effectuation logic. These firms used their existing means and relationships to enter the countries that they considered to have the most potential for their product offering. This extends the findings by Ojala (2009) indicating that firms may also select psychically close countries by using goal-oriented decision-making. While Finnish firms selected and entered foreign markets that were diverse, New Zealand firms 
conducted business in mainly psychically close countries, such as Australia, UK and USA. Furthermore, New Zealand firms typically have existing relationships in these countries. In their clustering of countries Ronen and Shenkar (1985) categorize these as Anglo countries in reference to their main language.

Firms that followed causal logic tended to be more adventurous in their FMS and FME because they entered psychically more distant countries, which involve a variety of cultures and institutional environments. Firms that followed effectuation placed more emphasis on their partners driving the internationalization ('who I know?') during FMS. This could be one reason why the Anglo cluster of countries is predominant for the New Zealand firms. This provides empirical evidence for the importance of being inside the network before a firm enters a foreign market that Johanson and Vahlne (2009) highlight. A counter argument would be that these existing relationships are constraining because they are based in countries which may not necessarily be the firm's most lucrative foreign markets.

Firms that followed causal logic started by strategically selecting the target country and subsequently searching for partners ('who I know?') to enter that market so that they could overcome the liability of outsidership, which consistent with Johanson and Vahlne (2009) is the main cause of uncertainty. Thus in the case of Finnish firms, partners helped them to achieve the market entry, but did not impact on the FMS. This might explain why Finnish firms entered more psychically distant markets. This finding supports the conceptualization by Johanson and Vahlne (2009) and the empirical findings by Ojala (2009) indicating that network relationships help to overcome psychic distance. It seems that firms following causation logic in their FMS are strategic and bold because they enter psychically and culturally more distant countries when compared to the firms using effectuation logic. Consequently, we develop the following proposition: 
Proposition 1: The more uncertain the host country institutional environment is the more likely international entrepreneurial firms are to follow causation instead of effectuation in FMS and FME.

One explanation why effectuation logic is pronounced in the FMEs could be that the first three markets generally represent the early stages of internationalization when the level of uncertainty is high. During the early stage of internationalization the firm is uncertain because it lacks market knowledge and resources and is therefore inclined to take a means-driven approach. These circumstances are similar to the uncertainty surrounding the new venture creation phase. Firms attempt to reduce the cost and uncertainty surrounding internationalization by using their trustful partners or people they already know such as friends and previous co-workers to create opportunities. They subsequently reduce risk by turning uncertainty into opportunities through these partners which is consistent with Palich and Bagby's (1996) perspective about entrepreneurs seeing opportunities where others see weaknesses and threats. Thus we develop the following proposition:

Proposition 2: International entrepreneurial firms are more likely to start making their FMS and FME decisions by following effectuation logic rather than causation logic.

Firms gain market and product knowledge through their partners who are already established in those markets. Consistent with Sarasvathy (2001) these firms focused on partnership to increase their means (effectuation) rather than competitor analysis to predict an uncertain future (causation), especially in their FMEs. The importance of partners was also visible in the firms' subsequent market entries. To compensate for their limited resources these firms leverage off their existing partnerships to benefit from their experience and market 
knowledge. During this process entrepreneurs focus on future events that they can control to help shape their future such as through their idiosyncratic abilities, their previous experience and their existing relationships.

Proposition 3: International entrepreneurial firms are more likely to make their FMS and FME decisions by focusing on their existing relationships instead of detailed competitor analysis.

We employ the three categories of means in effectuation and converge it with the decision-making process about FME to illustrate our contribution to internationalization process theory. First, the entrepreneur begins with identity ('who I am?’) e.g. their ability (software engineer) or trait such as having a positive outlook. Second, the entrepreneur asks about their knowledge of foreign markets, the industry, technology etc. ('what I know?'). Third, the entrepreneur asks about their network ('who I know?') to help them enter that market. Entrepreneurs spend a considerable amount of time identifying who is inside the network of their target country, such as who can introduce them to distributors or customers. Consequently, even though entrepreneurs use effectuation logic there is an element of planning in this process of seeking out 'who I know'? It is important that these stakeholders commit to the international expansion of firms by committing resources to reshape the goals (e.g. new products, new segments) of the project.

Consistent with Vissa and Bhagavatula (2012) we found that firms experience new entrants into their networks and exits which affects their portfolio of network partners and thus illustrates network dynamism. There is the simultaneous formation of new firms and new markets, and with this cycle of increased means also comes constraints for the growing network (Wiltbank et al., 2006) thus creating uncertainty. Interestingly, FMSs were not based on 
competitive analysis as Sarasvathy (2001) points out for causation logic but rather on the location of potential customers or partners. Combined with Johanson and Vahlne's (2009) concept of insidership, this illustrates that entrepreneurs behaved strategically by pursuing partners who would help position them inside the network in a foreign market to reduce uncertainty. In addition, since this international networking is both unplanned to benefit from surprise as well as planned it implies that causation and effectuation are interwoven and used as substitutes. Consequently, we develop the following propositions:

Proposition 4: The higher the uncertainty in FMS and FME the more likely international entrepreneurial firms are to interweave causation and effectuation logics as substitutes than to treat these two logics as distinct entities.

\section{CONCLUSIONS}

We provide empirical evidence to confirm that effectuation exists in actual decisionmaking by entrepreneurs about their FMS and FME. Since effectuation approach emphasizes exploitation of contingencies this enlightens us about how internationalizing firms gain knowledge and other resources and create opportunities through their relationships. Effectuation helps us understand the actions of entrepreneurs because they perceive uncertainty as providing opportunities for FMS and FME and not necessarily as a barrier that constrains their internationalization process. Our findings infer that firms using causation logic are learning more rapidly about foreign markets than the timid ones using effectuation logic and learning in incremental steps. This provides a challenge for the learning dimension of the internationalization process theory (Johanson and Vahlne, 1977; Johanson and Wiedersheim-Paul, 1975) by revealing that the type of logic used is closely linked to how entrepreneurial firms learn during their 
internationalization process. Based on the findings, however, we cannot be certain whether firms are more successful if they follow a specific logic in their internationalization decisions.

Since FMS and FME is a complex process we propose that it is meaningless to consider causation and effectuation logics as opposites on a continuum but to consider them as substitutes relating to the context of the decision-making. As table 3 shows these logics are not linear but are nuanced as they intertwine during decision-making and actual implementation of FMS and FME. This implies that they are used as alternatives depending on the context. Indeed, in her conceptualization Sarasvathy (2001) acknowledges the nature of causation and effectuation as, 'overlapping and intertwining over different contexts of decisions and actions' (p. 245) and that she deliberately contrasts them to draw out their theoretical implications. She contrasts them to bring out their theoretical contribution to the field of entrepreneurship. Our contribution, however, is to propose that they be considered as substitutes to draw out their theoretical contribution to internationalization process theory. This will help to clarify how entrepreneurs create opportunities and overcome risk and uncertainty in a diversity of foreign markets.

While current internationalization theories have the assumption of risk reduction and uncertainty avoidance in foreign markets we illustrate how entrepreneurs transform risk and uncertainty by using a means driven approach to create opportunities. Future theorizing on internationalization could be adapted by including concepts from effectuation, in particular means driven and affordable loss and how they influence decision making and the actual implementation of these decisions. This theorizing could also incorporate how effectuation logic (e.g. 'who do we know') in decision making can alleviate the 'liability of outsidership' and hence reduce uncertainty.

Table 3 provides several examples illustrating how firms recognize and create new opportunities during FMS and FME, which emerge through trustworthy relationships. These 
relationships are often formed in the domestic market and firms subsequently follow these clients into foreign markets. The relationship is, however, tested in foreign markets because of environmental uncertainty, competition and a different institutional environment thus illustrating the complexities, uncertainties and causal links. The level of trust in these relationships means that even though firms may have initial difficulties in foreign markets their partners make allowances for them by giving them time to adjust. Schweizer et al. (2010) and Sarasvathy et al. (2014) emphasize the positive aspects of relationships in their integration of effectuation and internationalization process theory. However, we contribute to these theories by questioning blind trust in relationships as we postulate that it is also important to include the negative aspects of relationships, such as opportunism and underperforming partners. A relationship that performs well in the domestic market can subsequently turn into a liability when venturing into foreign markets.

\section{Managerial Implications}

Our study has several implications for entrepreneurs. First, we question the strict adherence to business plans during the internationalization of the firm. Internationalizing entrepreneurs need to be flexible and open to surprises in order to recognize and create opportunities that allow the firm to evolve. These surprises enable them to find valuable partners who provide opportunities to gain insidership positions in lucrative foreign markets. Opportunities are not static but co-evolve with the internationalization context such as the entrepreneur's ability to absorb new knowledge about foreign markets and to experiment, as well as the institutional environment, customers, partners, competitors etc. By focusing on opportunities and positive outcomes entrepreneurs can lessen the constraints formed by risk and uncertainty in their decision-making. Second, 
entrepreneurs need to consider combining a means-driven approach as well as goal-driven approach during internationalization by using them as substitutes. They need to be flexible so that they can adapt to any changes they may need to make, for example, using goal-driven for market selection but substitute this to means-driven for market entry. Entrepreneurs engaged in solely causation-based activities could learn from those using effectuation and vice versa and to realize that these logics overlap and intertwine and can be used as substitutes. Third, entrepreneurs need to think in terms of affordable loss rather than predicted outcome to deal with risk and uncertainty while selecting and entering markets. For example, if they choose a distributor who fails to sell their products, they need to allow for the loss that they can afford to make (affordable loss).

Further Research Directions

Suggestions for future research directions include a qualitative study using other country and industry contexts to test the propositions and other findings in this study. Comparisons between other cross-country contexts could help determine whether firms target a diverse or narrow range of country clusters when selecting and entering their first three markets and what happens during subsequent international expansion. Different industry contexts will highlight whether effectuation is more relevant for some industries than others. For example, highly innovative industries may use effectuation logic more than traditional ones. Since this study focuses solely on SMEs an interesting question for future research is whether MNCs follow similar effectual networking processes that SMEs use in this study. This will help identify whether the effectual approach is only valid for SMEs with meagre resources or it also applies to MNCs who can benefit from it. Since our propositions and findings only generalize to theory this provides an 
opportunity for future researchers to develop a questionnaire that is used in a large quantitative survey so that statistical generalizations can be made. Research on causation and effectuation logic and their impact on international performance would shed light on the widening use of effectuation measures. Future research could consider studying several more FMSs and entries rather than restricting them to three as we have done. This could include entrepreneurial decisionmaking when faced with bureaucratic entry regulations and institutional environments in diverse foreign markets. Finally, a question for future research could be; to what extent relationships that are created through effectuation logic become liabilities later on?

\section{Acknowledgments:}

The authors would like to thank the anonymous reviewers for their valuable comments and suggestions. The New Zealand study was funded by a New Zealand Foundation for Research Science and Technology Grant. The study in Finland was funded by Need for Speed project governed by DIGILE Oy, the Marcus Wallenberg Foundation, and Foundation for Economic Education.

\section{Biographical Details:}

Sylvie Chetty is a Professor in the School of Business at University of Otago, New Zealand and is a Research Associate at Uppsala University in Sweden. Her research interests are in business networks, internationalization of entrepreneurial firms, social capital and industry clusters. She has published in journals such as, Journal of International Business Studies, Journal of World Business, Entrepreneurship Theory and Practice, European Journal of Marketing, Journal of International Marketing, Regional Studies, Management International Review, International Business Review and International Small Business Journal.

Arto Ojala is working as a senior researcher in the Department of Computer Science and Information Systems at the University of Jyväskylä, Finland. He is also Adjunct Professor in Software Business at the Tampere University of Technology. His research interests include software business and the internationalization of software firms. He has published in journals such as, Journal of International Marketing, International Business Review, IEEE Software, and Journal of Small Business Management.

Tanja Leppäaho works as Associate Professor of Entrepreneurship and International Business at the University of Jyvaskyla, School of Business and Economics. Her research on the internationalization of SMEs has been published in Entrepreneurship Theory and Practice, 
Journal of Small Business Management, International Business Review, and International Marketing Review among others. 


\section{REFERENCES}

Agndal, H. and Chetty, S. (2007), “The impact of relationships on changes in internationalisation strategies of SMEs”, European Journal of Marketing, Vol. 41 No11/12, 1449-1474.

Aharoni, Y. (1966). The foreign investment decision process. Boston, MA: Harvard Business School.

Akerlof, A.A. and Yellen, J.L. (1985), “Unemployment through the filter of memory”, Quarterly Journal of Economics, Vol. 100 No. 3, pp. 747-773.

Andersen, O. (1993), “On the internationalization process of firms: A critical analysis”, Journal of International Business Studies, Vol. 24 No. 2, pp. 209-231.

Ansoff, I. (1988), The New Corporate Strategy, John Wiley \& Sons: New York.

Brettel, M., Mauer, R., Engelen, A. and Kupper, D. (2012), "Corporate effectuation: Entrepreneurial action and its impact on R\&D project performance”, Journal of Business Venturing, Vol. 27 No. 2, pp. 167-184.

Brouthers, K.D. and van’t Kruis, Y.M. (1997), “Competing in software: Strategies for Europe’s niche business”, Long Range Planning, Vol. 30 No. 4, pp. 518-528.

Carland, J.W., Hoy, F., Boulton, W.R. and Carland, J.A.C. (1984), “Differentiating entrepreneurs from small business owners: A conceptualization”, The Academy of Management Review, Vol. 9, No. 2, pp. 354-359.

Casey, S.R. and Hamilton, R.T. (2014), "Export performance of small firms from small countries: The case of New Zealand”, Journal of International Entrepreneurship, DOI 10.1007/s10843-014-0126-4

Casson, M. (1982), Entrepreneur: An economic theory, Barnes and Noble Books: New Jersey. 
Chandler, G.N., DeTienne, D.R., McKelvie, A. and Mumford, T.V. (2011), "Causation and effectuation processes: A validation study”, Journal of Business Venturing, Vol. 26, pp. 375-390.

Chetty, S. and Agndal, H. (2007), "Social capital and its influence on changes in internationalization mode among small and medium-sized enterprises”, Journal of International Marketing, Vol. 15 No.1, pp. 1-29.

Chetty, S. and Campbell-Hunt, C. (2003), "Paths to internationalisation amongst small to medium-sized firms: a global versus regional approach”, European Journal of Marketing, Vol. 37 No. 5/6, pp. 796-820.

Coviello, N.E. (2006), “The network dynamics of international new ventures”, Journal of International Business Studies, Vol. 37 No. 6, pp. 713-731.

Coviello, N.E. and Martin, K.A-M. (1999), "Internationalization of service SMEs: An integrated perspective from the engineering consulting sector”, Journal of International Marketing, Vol. 7 No. 4, pp. 42-66.

Dow, D. (2000), “A note on psychological distance and export market selection”, Journal of International Marketing, Vol. 8 No. 1, pp. 51-64.

Eisenhardt, K.M. (1989a). "Building theories from case study research", Academy of Management Review, 14(4), 532-550.

Eisenhardt, K.M. (1989b), “Making fast strategic decisions in high-velocity environments”, Academy of Management Journal, Vol. 32 No. 3, pp. 543-576.

Eisenhardt, K.M., and Graebner, M.E. (2007), “Theory building from cases: Opportunities and challenges”, Academy of Management Journal, Vol. 50 No. 1, pp. 25-32. 
Figueira-de-Lemos, F., Johanson, J. and Vahlne, J-E. (2011), "Risk management in the internationalization process of the firm: A note on the Uppsala Model," Journal of World Business, Vol. 46 No2, pp. 143-53.

Fisher, G. (2012), “Effectuation, causation, and bricolage: A behavioral comparison of emerging theories in entrepreneurship research”, Entrepreneurship Theory and Practice, Vol. 36 No. 5, pp. 1019-1051.

Frishammar, J. and Andersson, S. (2009), “The overestimated role of strategic orientations for international performance in smaller firms”, Journal of International Entrepreneurship, Vol. 7 No. 1, pp. 57-77.

Gulati, R. Nohria, N. and Zaheer, A. (2000), “Strategic networks”, Strategic Management Journal, Vol. 21, pp. 203-215.

Gruber, M., MacMillan, I.C. and Thompson, J.D. (2012), “From minds to markets: How human capital endowments shape market opportunity identification of technology start-ups”, Journal of Management, Vol. 38 No. 5, pp. 1421-1449.

Hilmersson, M. and Jansson, H. (2012), "Reducing uncertainty in the emerging market entry process: On the relationship among international experiential knowledge, institutional distance, and uncertainty”, Journal of International Marketing, Vol. 20, No. 4, pp. 96-110.

Huber, G.P. and Power, D.J. (1985), "Retrospective reports of strategic-level managers: guidelines for increasing their accuracy”, Strategic Management Journal, Vol. 6, pp. 171180.

Johanson, J. and Mattsson L.-G. (1988), "Internationalisation in industrial systems - A network approach”. In N. Hood and J-E. Vahlne (eds.), Strategies in Global Competition: 287-314. Croom Helm: London. 
Johanson, J. and Vahlne, J.-E. (1977), “The internationalization process of the firm - a model of knowledge development and increasing foreign market commitments”, Journal of International Business Studies, Vol. 8 No. 1, pp. 23-32.

Johanson, J. and Vahlne, J.-E. (1990), “The mechanism of internationalization”, International Marketing Review, Vol. 7 No. 4, pp. 11-24.

Johanson, J. and Vahlne, J.-E. (2009), “The Uppsala internationalization process model revisited: From liability of foreignness to liability of outsidership”, Journal of International Business Studies, Vol. 40, pp. 1411-1431.

Johanson, J. and Wiedersheim-Paul, F. (1975), "The internationalization of the firm: four Swedish cases”, Journal of Management Studies, Vol. 12 No. 3, pp. 305-322.

Kotler, P. (1991). Marketing Management. Prentice-Hall: NJ.

Loane, S., Bell, J. and McNaughton, R. (2007), “A cross-national study on the impact of management teams on the rapid internationalization of small firms”, Journal of World Business, Vol. 42 No. 4, pp. 489-504.

Mainela, T. and Puhakka, V. (2009), “Organising new business in a turbulent context: Opportunity discovery and effectuation for IJV development in transition markets", Journal of International Entrepreneurship, Vol. 7, pp.111-134

Marschan-Piekkari, R. and Welch, C. (2004), "Qualitative research methods in international business: the state of the art”. In R. Marschan-Piekkari and C. Welch (Eds.), Handbook of Qualitative Research Methods for International Business: 5-24. Edward Elgar: UK.

Miles, M.B. and Huberman, A.M. (1994), Qualitative Data Analysis: An Expanded Sourcebook. Sage Publications: California. 
Miller, C.C., Cardinal, L.B. and Glick, W.H. (1997), "Retrospective reports in organizational research: A reexamination of recent evidence”, Academy of Management Journal, Vol. 40 No. 1, pp. 189-204.

Moen, O., Gavlen, M., and Endresen, I. (2004), "Internationalization of small, computer software firms: Entry forms and market selection”, European Journal of Marketing, Vol. 38 No. 910, pp. 1236-1251.

Ojala, A. (2009), "Internationalization of knowledge-intensive SMEs: The role of network relationships in the entry to a psychically distant market”, International Business Review, Vol. 18 No. 1, pp. 50-59.

Ojala, A. and Tyrväinen, P. (2007), "Market entry and priority of small and medium-sized enterprises in the software industry: An empirical analysis of cultural distance, geographical distance, and market size”, Journal of International Marketing, Vol. 15 No. 3, pp. 123-149.

Oviatt, B. and McDougall, P. (1994), “Toward a theory of international new ventures”, Journal of International Business Studies, Vol. 25 No. 1, pp. 45-64.

Palich, L.E., and Bagby, D.R. (1995), “Using cognitive theory to explain entrepreneurial risktaking: Challenging conventional wisdom”, Journal of Business Venturing, Vol. 10, pp. 425-438.

Perry, J.T., Chandler, G.N. and Markova, G. (2012), "Entrepreneurial effectuation: A review and suggestions for future research”, Entrepreneurship Theory and Practice, Vol. 36 No. 4, pp. 837-861.

Pettigrew, A.M. (1990), "Longitudinal field research on change: Theory and practice", Organization Science, Vol. 1 No. 3, pp. 267-292. 
Powell, W. and Sandholtz, K.W. (2012), “Amphibious entrepreneurs and the emergence of organizational forms”, Strategic Entrepreneurship Journal, Vol. 6, pp. 94-115.

Read, S., Dew, N., Sarasvathy, S.D., Song M. and Wiltbank R. (2009), “Marketing under uncertainty: The logic of an effectual approach”, Journal of Marketing, Vol. 73 No. May 2009, pp. 1-18

Ronen, S. and Shenkar, O. (1985), “Clustering countries on attitudinal dimensions: A review and synthesis”, The Academy of Management Review, Vol. 10 No. 3, pp. 435-454.

Sarasvathy, S.D. (2001), “Causation and effectuation: Towards a theoretical shift from economic inevitability to entrepreneurial contingency”, Academy of Management Review, Vol. 26, pp. 243-288.

Sarasvathy, S.D. (2008). Effectuation: Elements of Entrepreneurial Expertise. New Horizons in Entrepreneurship. Edgar Elgar: Cheltenham.

Sarasvathy, S., Kumar, K., York J.G. and Bhagavatula, S. (2014), "An effectual approach to international entrepreneurship: Overlaps, challenges, and provocative possibilities", Entrepreneurship Theory \& Practice, Vol. 38, No. 1, pp. 71-93.

Sarasvathy, S.D., Venkataraman, S., Dew, N. and Velamuri, R. (2003), “Three views of entrepreneurial opportunity”. In Z. J. Acs and D. B. Audretsch (Eds.), Handbook of Entrepreneurship Research: An Interdisciplinary Survey and Introduction: pp. 141-160. Kluwer Academic: London.

Schweizer, L. (2005), “Organizational integration of acquired biotechnology companies into pharmaceutical companies: The need for a hybrid approach”, Academy of Management Journal, Vol. 48 No. 6, pp. 1051-1074.

Schweizer, R., Vahlne, J.E. and Johanson, J. (2010), “Internationalization as an entrepreneurial process”, Journal of International Entrepreneurship, Vol. 8 No. 4, pp. 343-370. 
Shane, S. and Venkataraman, S. (2000), "The promise of entrepreneurship as a field of research", Academy of Management Review, Vol. 26 No.1, pp. 13-17.

Stake, R.E. (1995). The art of case study research. Sage Publications: California.

Stuart, R., Michael, S. and Willem, S. (2009), “A meta-analytic review of effectuation and venture performance”, Journal of Business Venturing, Vol. 24, pp. 573-587.

Tsang, D. (2005), “Growth of indigenous entrepreneurial software firms in cities”, Technovation, Vol. 25 No. 11, pp. 1331-1336.

Uzzi, Brian (1997), "Social structure and competition in inter-firm networks: The paradox of embeddedness,” Administrative Science Quarterly, 42 (2), 35-67.

Vissa, B. and Bhagavatula, S. (2012), “The causes and consequences of churn in entrepreneurs' personal networks”, Strategic Entrepreneurship Journal, Vol. 6 No. 3, pp. 273-289.

Wiltbank, R., Read, S., Dew, N. and Sarasvathy, S.D. (2009), "Prediction and control under uncertainty: Outcomes in angel investing”, Journal of Business Venturing, Vol. 24, pp. 116-133.

Yin, R.K. (2003), Case Study Research: Design and Methods, Sage Publications: California.

Zahra, S.A and Bogner, W.C. (2000), “Technology strategy and software new ventures' performance: Exploring the moderating effect of the competitive environment”, Journal of Business Venturing, Vol. 15 No. 2, pp. 135-173.

Zahra, S.A. and George, G. (2002), “Absorptive capacity: A review, reconceptualization and extension”, Academy of Management Review, Vol. 27 No. 2, pp. 185-203.

Zahra, S.A., Korri, J.S. and Yu, J. (2005), "Cognition and international entrepreneurship: implications for research on international opportunity recognition and exploitation", International Business Review, Vol. 14 No. 2, pp. 129-146. 
Table 1-Comparison of Causation, Effectuation and Uppsala Internationalization process model

\begin{tabular}{|c|c|c|c|}
\hline Categories & Causation & Effectuation & $\begin{array}{l}\text { Internationalization } \\
\text { Process }\end{array}$ \\
\hline $\begin{array}{l}\text { Decision-making } \\
\text { logic }\end{array}$ & $\begin{array}{l}\text { Goal driven focusing } \\
\text { on outcomes }\end{array}$ & $\begin{array}{l}\text { Means driven } \\
\text { focusing on resources }\end{array}$ & $\begin{array}{l}\text { Goal and Means } \\
\text { driven } \\
\text { focusing on resources } \\
\text { and process }\end{array}$ \\
\hline $\begin{array}{l}\text { Attitude towards the } \\
\text { market }\end{array}$ & $\begin{array}{l}\text { Firm and market are } \\
\text { separate }\end{array}$ & $\begin{array}{l}\text { Create the market } \\
\text { through means driven } \\
\text { approach }\end{array}$ & $\begin{array}{l}\text { Create the market by } \\
\text { gaining an insidership } \\
\text { position in the } \\
\text { network }\end{array}$ \\
\hline Strategy & $\begin{array}{l}\text { Competitive } \\
\text { Exploitation of pre- } \\
\text { existing knowledge }\end{array}$ & $\begin{array}{l}\text { Collaborative } \\
\text { Exploitation of } \\
\text { contingencies }\end{array}$ & $\begin{array}{l}\text { Collaborative } \\
\text { Exploitation of pre- } \\
\text { existing knowledge }\end{array}$ \\
\hline $\begin{array}{l}\text { Attitude towards } \\
\text { unexpected events }\end{array}$ & $\begin{array}{l}\text { Plan and market } \\
\text { research to have } \\
\text { detailed competitor } \\
\text { analysis } \\
\text { Prediction of an } \\
\text { uncertain future }\end{array}$ & $\begin{array}{l}\text { Control of an } \\
\text { uncertain future }\end{array}$ & $\begin{array}{l}\text { Open to surprises as } \\
\text { well as plan and } \\
\text { market research } \\
\text { Prediction/Control of } \\
\text { an uncertain future }\end{array}$ \\
\hline Context & $\begin{array}{l}\text { Predictable because } \\
\text { reduces risk }\end{array}$ & $\begin{array}{l}\text { Uncertainty creates } \\
\text { opportunities }\end{array}$ & $\begin{array}{l}\text { Uncertainty reduction } \\
\text { by collaborating with } \\
\text { partners }\end{array}$ \\
\hline Outcomes & Maximize returns & Affordable loss & $\begin{array}{l}\text { Process model } \\
\text { focusing on resources }\end{array}$ \\
\hline Unit of analysis & Firm & $\begin{array}{l}\text { Entrepreneur- } \\
\text { individual }\end{array}$ & Firm \\
\hline
\end{tabular}


TABLE 2. PROFILE OF SOFTWARE FIRMS IN THIS STUDY

\begin{tabular}{|c|c|c|c|c|}
\hline Firm & Industry & $\begin{array}{l}\text { Number of } \\
\text { Employees }\end{array}$ & Year of Inception & $\begin{array}{l}\text { Year of First International } \\
\text { Sales }\end{array}$ \\
\hline FIN1 & Game players & 25 & 2000 & 2003 \\
\hline FIN2 & $\begin{array}{l}\text { Telecom } \\
\text { operators }\end{array}$ & 30 & 1998 & 2000 \\
\hline FIN3 & $\begin{array}{l}\text { Bank and } \\
\text { financing } \\
\text { sector }\end{array}$ & 20 & 2006 & 2006 \\
\hline FIN4 & $\begin{array}{l}\text { Financial } \\
\text { institutions } \\
\text { and } \\
\text { government } \\
\text { organizations }\end{array}$ & 12 & 2008 & 2009 \\
\hline FIN5 & $\begin{array}{l}\text { Furniture } \\
\text { chains and } \\
\text { furniture } \\
\text { manufacturers }\end{array}$ & 30 & 2006 & 2007 \\
\hline NZ1 & $\begin{array}{l}\text { Telephony } \\
\text { integration }\end{array}$ & 100 & 1994 & 1996 \\
\hline NZ2 & Fenestration & 30 & 1985 & 1988 \\
\hline NZ3 & Healthcare & 250 & 1993 & 1993 \\
\hline NZ4 & $\begin{array}{l}\text { Business } \\
\text { processes }\end{array}$ & 25 & 1999 & 2005 \\
\hline NZ5 & Soft Starters & 85 & 1978 & 1980 \\
\hline
\end{tabular}




\section{TABLE 3. SIGNIFICANCE OF CAUSATION AND EFFECTUATION LOGICS IN FMS AND FME OF THE FIRMS}

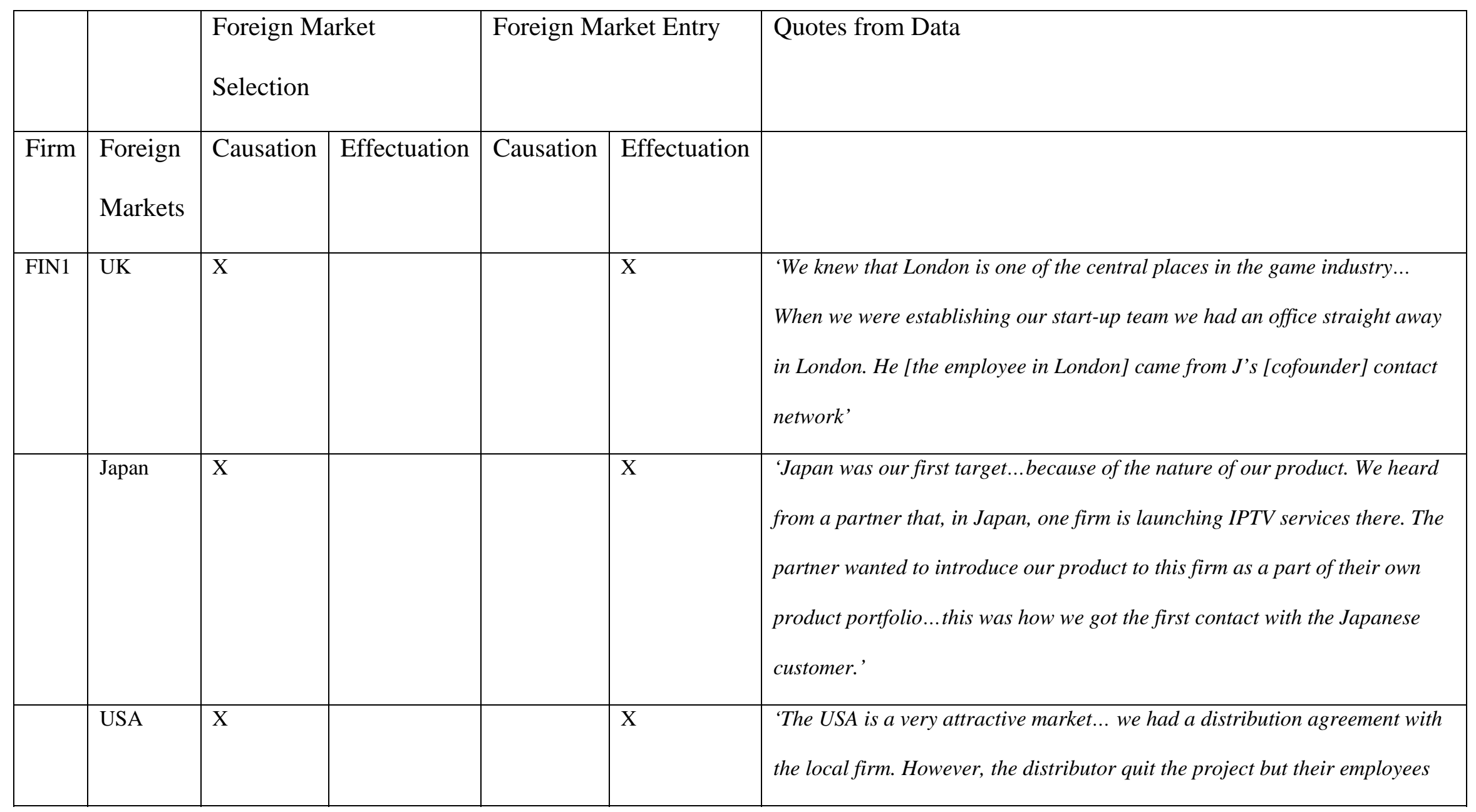




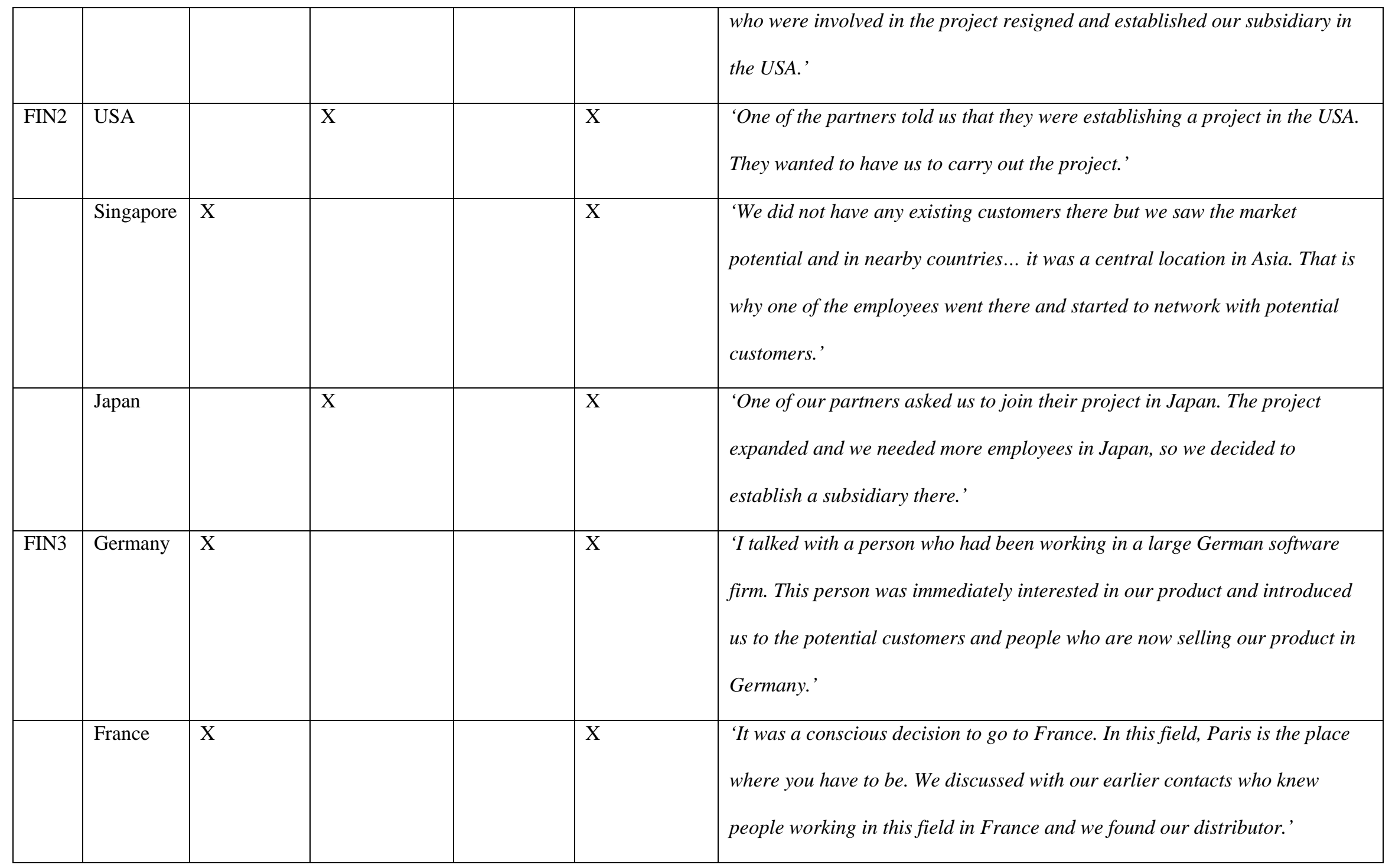




\begin{tabular}{|c|c|c|c|c|c|}
\hline & Russia & $\mathrm{X}$ & & $\mathrm{X}$ & $\begin{array}{l}\text { 'Russia was the place where we wanted to locate because we knew that there } \\
\text { are a lot of potential customers. We found our representative for the Russian } \\
\text { markets by using our personal contacts.' }\end{array}$ \\
\hline FIN4 & Sweden & $\mathrm{X}$ & $\mathrm{X}$ & & $\begin{array}{l}\text { 'I conducted a market survey by using a consultant. He gave me a list of ten } \\
\text { potential distributors. Now we have a distribution agreement with one of } \\
\text { them.' }\end{array}$ \\
\hline \multirow[t]{2}{*}{ FIN5 } & Italy & $\mathrm{X}$ & & $\mathrm{X}$ & $\begin{array}{l}\text { 'We conducted a market research in Italy and one part of it was to find } \\
\text { potential partners. However, we did not find the distributor based on the } \\
\text { market research, we found him accidentally. They saw our product on the } \\
\text { Internet and they contacted us.' }\end{array}$ \\
\hline & Denmark & $\mathrm{X}$ & $\mathrm{X}$ & & $\begin{array}{l}\text { 'Denmark is a good strategic location; it is close to Sweden and Norway } \\
\text { where our main customers are located. With help from Finnish export agency } \\
\text { we found a person from Denmark with a strong background in the furniture } \\
\text { industry. He was interested in joining our team and we established a sales } \\
\text { office in Denmark.' }\end{array}$ \\
\hline
\end{tabular}




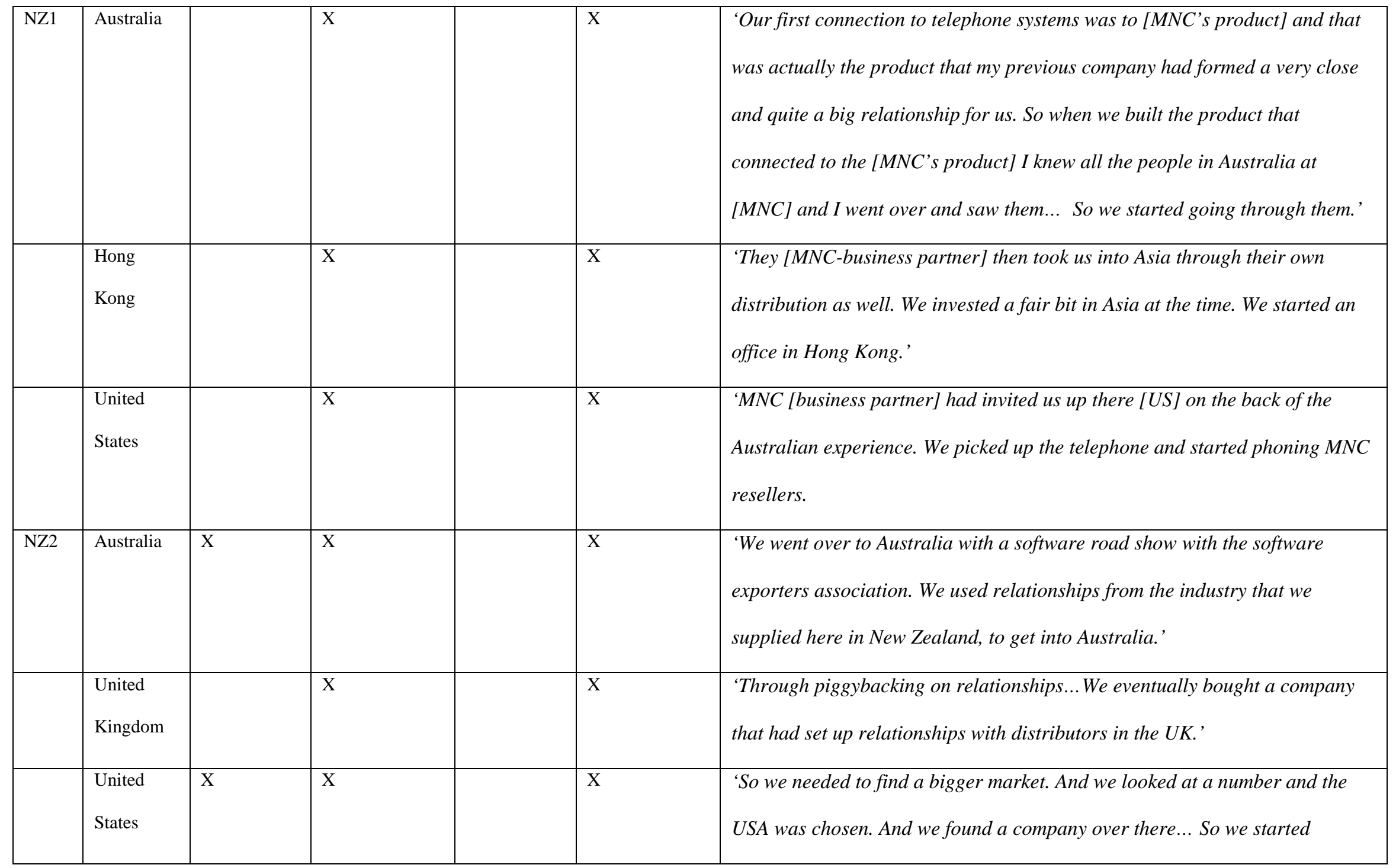




\begin{tabular}{|c|c|c|c|c|c|c|}
\hline & & & & & & $\begin{array}{l}\text { developing some software for them and they provided funding and in fact } \\
\text { were our partners in the USA.' }\end{array}$ \\
\hline \multirow[t]{2}{*}{ NZ3 } & $\begin{array}{l}\text { United } \\
\text { States of } \\
\text { America }\end{array}$ & $\mathrm{X}$ & & $\mathrm{X}$ & $\mathrm{X}$ & $\begin{array}{l}\text { 'Well you sort of thought one day you may sell overseas...The software we } \\
\text { wrote for that we productized and then starting selling it over the Internet and } \\
\text { this was back in '92/93.' }\end{array}$ \\
\hline & Canada & & $\mathrm{X}$ & & $\mathrm{X}$ & $\begin{array}{l}\text { 'Via internet into North America [US and Canada]...entered Canada through } \\
\text { referrals and from existing partnerships' }\end{array}$ \\
\hline \multirow[t]{2}{*}{ NZ4 } & Australia & & $X$ & & $\mathrm{X}$ & $\begin{array}{l}\text { 'Australian sales began when }[R D] \text {, from a company called [ABC] based in } \\
\text { Sydney, asked if he could sell the software.' }\end{array}$ \\
\hline & $\begin{array}{l}\text { United } \\
\text { Kingdom }\end{array}$ & & $X$ & & $\mathrm{X}$ & $\begin{array}{l}\text { 'When I first came back to New Zealand I was approached by this Kiwi who } \\
\text { had heard about me and he tried to get me interested in some ventures he was } \\
\text { involved with... he said, pay me a retainer and I'll sell in the UK. He sold for } \\
\text { us in the UK and he's been in our footprint ever since.' }\end{array}$ \\
\hline
\end{tabular}




\begin{tabular}{|c|c|c|c|c|c|c|}
\hline NZ5 & $\begin{array}{l}\text { United } \\
\text { Kingdom }\end{array}$ & & $\mathrm{X}$ & & $\mathrm{X}$ & $\begin{array}{l}\text { Obtained unsolicited orders from distributors. 'NZ5 was selling in the UK } \\
\text { market in } 1980 \text { before it had even sold its products domestically. '... our } \\
\text { distributors had jumped into bed with this [product] really quickly because } \\
\text { nobody wanted to miss out on getting the rights to sell this product.' }\end{array}$ \\
\hline & Australia & $\mathrm{X}$ & & & $\mathrm{X}$ & $\begin{array}{l}\text { Had to proactively sell its products ...'Its more expensive, but its better. So } \\
\text { we had to go in and tell people why.' A positive response led it to develop its } \\
\text { own sales operations in Australia. }\end{array}$ \\
\hline & $\begin{array}{l}\text { United } \\
\text { States }\end{array}$ & $\mathrm{X}$ & & $\mathrm{X}$ & $\mathrm{X}$ & $\begin{array}{l}\text { Entered the US by proactively selling the product through strategic } \\
\text { educational approach. '... a lot of that [developing major international } \\
\text { markets] is relationship and timing, which you can't create but it's a bit like } \\
\text { golfing...the more you practice the luckier you get' }\end{array}$ \\
\hline
\end{tabular}

